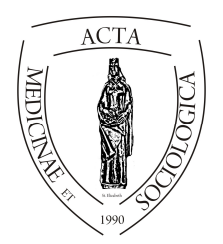

Acta Medicinae et

Sociologica (2020)

UNIVERSITY OF

DEBRECEN

Vol. 11., Különszám. (99-109)

FACULTY OF

HEALTH

doi:

NYÍREGYHÁZA

\title{
A fogyatékkal élők sportolási lehetőségei és motivációs tényezői
}

\author{
Varga Ábrahám ${ }^{1}$, Balatoni Ildikó ${ }^{2}$ \\ ${ }^{1}$ ügyvivő szakértő, Debreceni Egyetem Klinikai Központ Elnöki Hivatal, 4032 Debrecen, Nagyerdei krt.98. \\ ${ }^{2}$ operatív igazgató, Debreceni Egyetem Klinikai Központ Operatív Igazgatóság, 4032 Debrecen, Nagyerdei krt.98.
}

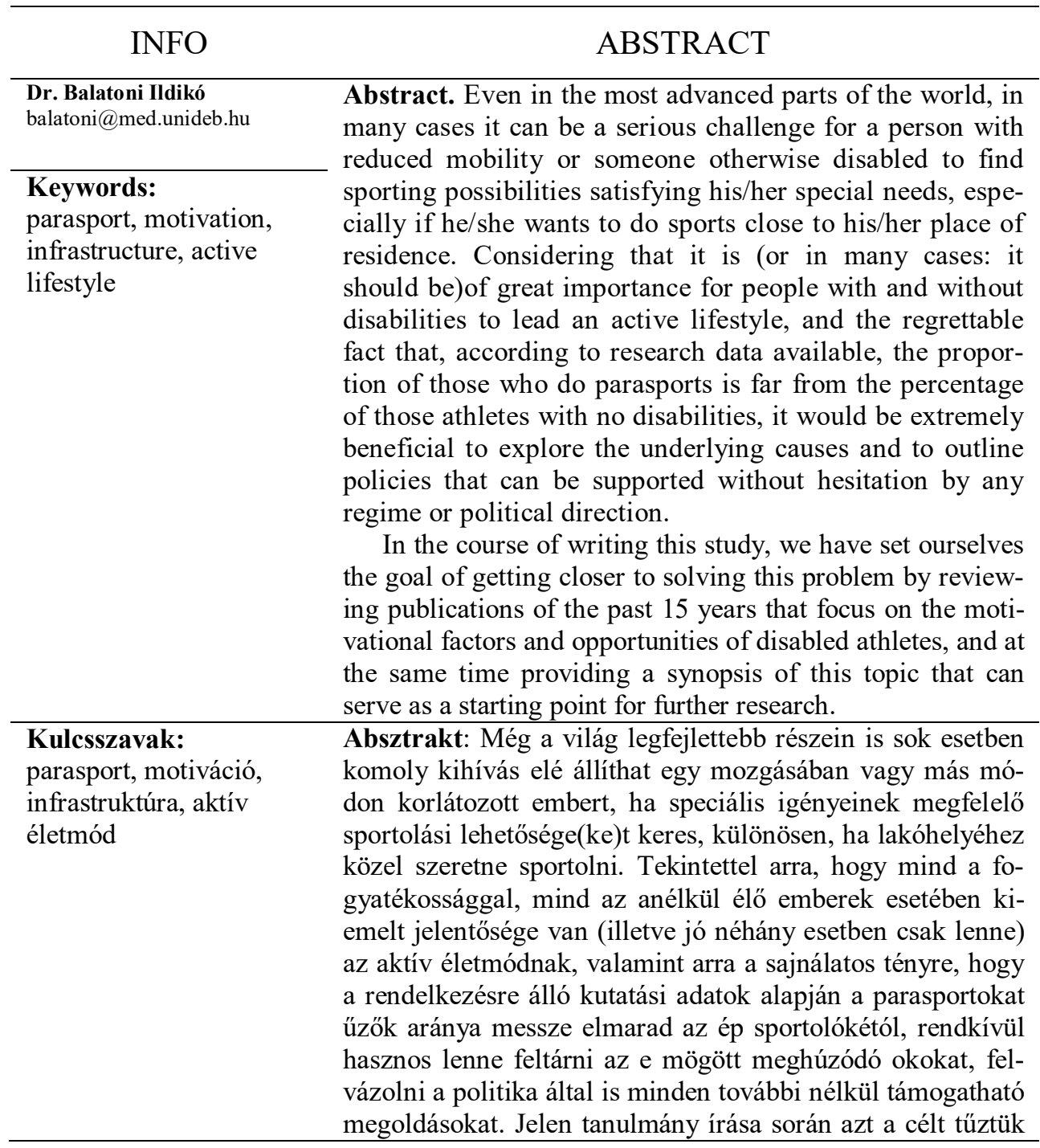


magunk elé, hogy az elmúlt 15 év fogyatékos sportolói motivációkat és lehetőségeket középpontba állító publikációnak áttekintése révén közelebb kerüljünk ennek a problémának a megoldásához, egyben egy olyan összefoglalását adjuk a témának, ami újabb kutatások kiindulópontjául szolgálhat.

A publikáció elkészítését az EFOP-3.6.2-16-2017-00003 számú projekt támogatta. A projekt az Európai Unió támogatásával, az Európai Szociális Alap társfinanszírozásával valósult meg.

\section{Bevezetés}

A világ lakosságának jelenleg közel 15\%-a él valamifajta fogyatékossággal, akiknek 2-4\%-át ez a körülmény nagymértékben akadályozza mindennapi életvitelében. A WHO e legfrissebb adata jóval magasabb a korábbi, 10\% körüli becslésnél, hiszen ilyen módon a fogyatékosság különböző formái több mint 1 milliárd embert érintenek világszerte (World Health Organization 2011). Az Európai Unión belül az arányok hasonlóak, az itt élők egyhatoda, a 75 év felettiek több mint 30\%-a él valamilyen fogyatékossággal, utóbbiak 20\%-ának ,életvitelét pedig jelentős mértékben korlátozza a fogyatékosság" (Európai Bizottság 2010).

Az OECD-országok többségében a nők aránya a fogyatékossággal élök között magasabb, mint a férfiaké,a társadalom elöregedésével pedig szinte bizonyos, hogy ez a szám mindkét nem esetében növekedni fog. Azokban az országokban, ahol a várható élettartam 70 évnél magasabb, az emberek átlagosan 8 évet, vagyis élettartamuk 11,5\%-át kénytelenek fogyatékossággal leélni (Disabled World 2019).

A fogyatékossággal élők csoportján belül a kerekesszékesek globális aránya majdnem 2\%-ra tehető, vagyis több mint 130 millió ember tartozik e körbe. Számottevő különbség tapasztalható ugyanakkor a fejlett és fejlődő országok arányait illetően: míg előbbiben az össznépesség 1\%-a, azaz 10 millió ember, addig utóbbiban legalább 2\%, mintegy 122 millió ember érintett (Wheelchair Foundation 2016).

Jól látható tehát, hogy egy igen népes társadalmi csoportról van szó, akiknek az életvitele szempontjából rendkívül fontos, hogy bizonyos jogi, környezeti, szociális, infrastrukturális feltételek adottak legyenek. Ezek garantálása össztársadalmi erőfeszítést és együttmüködést igényel, de természetesen a politikának, a jogalkotói és gazdasági döntéshozói helyzetben lévőknek jelentős igazán az erre vonatkozó felelőssége.

A fogyatékossággal élők egyik legmeghatározóbb nehézsége, mellyel többnyire napi szinten, az élet majd' minden területén kénytelenek szembenézni, az izoláció. Amellett, hogy a fent említett politikai szándék is hangsúlyos a kirekesztettség megszüntetése és a társadalom érzékenyítése aspektusából, rendkívül lényegesek azok a belső motivációs tényezők, amelyek aktív életmódra, a szociális kapcsolatok fenntartására és bővítésére, új célok megfogalmazására és elérésére ösztönöznek.

A rendszeres fizikai aktivitás és az ilyen jelleggel űzött sport bármely formája köztudomásúlag - egyben tudományosan alátámasztott módon - alkalmas a testilelki egészség és a pszichoszociális jóllét javítására, a szorongás oldására, csapatban üzött változatai pedig a társas kapcsolatok kialakításának, megerősítésének is kiváló eszközei. Mindezekből következik, hogy a fogyatékossággal élök körében különös jelentősége van annak, hogy - lehetőségeikhez mérten - minél többen végezzenek 
rendszeres testmozgást, vegyenek részt fizikai aktivitással (is) járó közösségi alkalmakon, csapatsporteseményeken.

Kanadában, a világ egyik legfejlettebb országában, jelenleg mintegy 4,4 millió ember - a lakosság 14\%-a - él valamifajta fogyatékossággal, akiknek valamivel kevesebb mint 1\%-a vesz részt szervezett sportprogramokban (összehasonlításképpen: az ép kanadaiak mintegy 31\%-a sportol). Magyarországon a kifejezett fogyatékossággal élök száma 2011 és 2016 között 491 ezerről 408 ezerre - vagyis 5\% alá apadt (Szepesi 2018), közülük ugyanakkor a legnépesebb, a mozgásukban korlátozott csoport tagjai körében a sporttevékenységet végzők aránya alacsonyabb még a kanadai társaikénál is, lévén 0,5\% körül van (Központi Statisztikai Hivatal 2008).

Márpedig a társadalom valamennyi tagja szempontjából kiemelkedő a sport fogyatékossággal élők esetében betöltött és lényegesen kibővült - így többek közt a károsodott mozgásfunkciók helyreállításával/korrekciójával/kompenzációjával kapcsolatos - szerepének erősítése, különösen az izoláció mérséklése - megszüntetése és a testi-lelki jóllét fokozása érdekében. Az önelfogadás, a teljesértéküség és a társadalmi beágyazottság/integráltság érzete az egyik, az elöítélet-mentesség, a támogatói attitüd és a tolerancia növelése a másik oldalon olyan kívánatos célok, melyek mindannyiunk számára élhetőbb, teljesebb emberi életet, egészségesebb társadalmat, harmonikusabb egymás mellett élést eredményeznek.

Fentiekre tekintettel azt a célt tüztük ki, hogy a parasportokat - elsősorban azok kerekesszékes formáit - üzők magyarországi és globális helyzetével kapcsolatos szakirodalmat áttekintsük, mindenekelőtt arra fókuszálva, hogy mozgásukban korlátozott embertársaink milyen feltételekkel, gyakorisággal és infrastrukturális adottságok mellett tudják választott sportjukat üzni, mely motivációs tényezők a leginkább relevánsak sportolásuk szempontjából, illetve a rendszeres fizikai igénybevétel/aktivitás milyen formán segíti a sporton kívüli életvitelüket.

\section{Az integráció és a sport szerepe a fogyatékos emberek életében}

Egy adott társadalom milyenségét nagymértékben meghatározza, hogy tagjai miként viszonyulnak a hátrányos helyzetü, periférián lévő vagy épp veleszületett vagy szerzett fogyatékossággal élő társaikhoz. Vagy ahogy Foucault (2000: 62) mondja: „minden betegségnek csak olyan kultúrában van valósága és értéke, amely betegségként ismeri fel."

Bármennyire is kívánatos lenne ugyanakkor, rendkívül nehéz egy olyan, egyértelmü társadalompolitikai irány kijelölése, amely valamennyi hátrányos helyzetü csoport teljes - vagy akár csak nagyarányú - elfogadását eredményezné. Az esetek jelentős részében az integratív szemléletü oktatás - ilyen értelemben is - hatékony tud lenni, miként ezt a skandináv modell példázza. Ennek a már a 70-es évek óta müködő rendszernek köszönhetően, mely a lehető legszélesebb körü integrációt célozza, a fogyatékos gyermekek számára biztosítva van a lakóhelyükhöz közeli iskola látogatásának lehetősége (Szekeres 2011). Más, az elöítéletességet középpontba állító vizsgálatok azonban azt látszanak alátámasztani, hogy nincs szignifi- 
káns kapcsolat a tapasztalatok mennyisége és az elfogadás mértéke között. Sőt egyes kutatások e két jellemző negatív korrelációját hangsúlyozzák (Pinczés 2018).

Akármelyik irányzat mellett is köteleződjenek el a döntéshozók a társadalom érzékenyítése szempontjából, létezik egy olyan formája a fogyatékossággal élők támogatásának, amelyet orvos-egészségügyi és pszicho-szociális szempontból is tudományos konszenzus övez: a sport.

A sport nem csupán a hozzá szorosan kötődő kompetenciák fejlesztésére alkalmas, hanem az érzelmi stabilitás és a pozitív önértékelés megjelenésén keresztül a személyiség egy sor egyéb részére is előnyös hatást gyakorol. Márpedig ennek miként Kasum és Mladenović írják egy 2017-es tanulmányukban - jelentős szerepe lehet az általános értelemben vett pozitív énkép és optimális müködés (jóllét) kialakításában, és - ezzel szoros összefüggésben - abban, hogy az egyén a fogyatékosságát valamiképp elfogadja, és azt az identitása részévé tegye. Mindez ráadásul nagyon erősen ellene hat a fogyatékos emberek egyik gyakori problémájának, az izolációnak is, és hosszabb távon szélesebb körü társadalmi integrációt tesz lehetővé (Kasum és Mladenović 2017).

Fontos kérdés ezzel összefüggésben, hogy egy fogyatékossággal élö embernek milyen, sporttal kapcsolatos motivációi vannak, illetve - amennyiben nem sportol mi áll inaktivitása hátterében. A felvetés már csak azért is lényeges, mivel számottevő eltérés mutatkozik például a mozgásukban korlátozottak és az épek sportolási hajlandóságában - amiként azt a magyar és a külföldi adatok is igazolják. A kérdés ráadásul még annál is összetettebb, mint amilyennek első ránézésre tünhet, hiszen a fizikai akadályok/nehézségek közel sem az egyedüli összetevők, melyek a sportolási szokások kapcsán észlelhető nagyfokú eltéréseket magyarázzák.

Ezzel kapcsolatban eddig egymásnak ellentmondani látszó kutatási eredmények születtek. Egyrészről a már valamely sportot üzők esetén nem figyelhető meg érdemi különbség a sporttal kapcsolatos motiváció és a megküzdési módok tekintetében fogyatékossággal és anélkül élők között, amiből Perreault és Vallerand arra következtetnek, hogy ezek az emberek - ti. a sportolók - sokkalta inkább hasonlóak, mint különbözőek (Perreault és Vallarand 2007). Másfelől, a fogyatékossággal élő sportolók eddigi vizsgálatai több ízben is arra világítottak rá, hogy mind a sportolással, mind az egészséggel kapcsolatos tényezők jelentős szerepet játszanak a különböző sportágak kiválasztásakor. Kerekesszékes kosárlabdázókkal kapcsolatos kutatások során azonban kiderült, hogy e sportolók választásában az egészséggel összefüggő szempontok nem voltak igazán meghatározóak. Az eredmények alapján leszürhető, hogy - egyebek mellett - a csapatmunka és a sportolás nyomán felszabaduló érzelmek jelentették a fö motivációt a kerekesszékes kosárlabda és rögbi kiválasztásakor. Mindent összevetve, általánosabb érvénnyel leszögezhető: minél nagyobb mértékü az egyén fogyatékossága, annál nagyobb súllyal esnek latba a sportolás egészségügyi szempontjai (Bartosz, Zubala és munkatársai 2010).

Természetesen a motivációk elemzése során nagyon tanulságos lehet az is, ha maguktól az érintettektől hallhatunk arról, mit jelent nekik a sport, és milyen okból kezdték el azt üzni. Powell és Myers (2017) tanulmányában több, ilyen jellegü beszámolót is olvashatunk.

A sport „...a kevés alkalmak egyike, amikor nem érzem magam fogyatékosnak. Ami elég vicces, mert közben nyilván tudom, hogy egy kerekesszékben ülve 
parasportolok, de ez mégis másmilyen érzés, mert közben valódi sportot üzök, rögbizem, ugyanúgy, mintha ép lennék...Vélhetően ez tehát az egyetlen olyan alkalom, amikor nem érzem magam fogyatékosnak, mert az van bennem, hogy csak egy sportoló vagyok, aki azt a sportot üzi, amit egyébként imád" (Powell és Myers 2017: 8; a szerzők fordítása).

„...végiggondoltam, merre is tart az életem, mikor végül megismerkedtem a kerekesszékes rögbivel. Ettől kezdve tudtam, hogy az életemnek ez egy nagyon hangsúlyos része lesz, és hogy a legjobb akarok benne lenni. A legjobb akartam lenni a saját kategóriámon belül, és Nagy-Britanniát akartam képviselni. Szóval ezeket a kezdetektől fogva tudtam, és úgy gondolom, hogy ez segített a sérüléseimmel kapcsolatosan és a rehabilitációmban is, illetve abban, hogy koncentrált tudjak maradni, mert rájöttem, hogy ez az, amit csinálni akarok, amibe minden időmet, energiámat és koncentrációmat bele akarom fektetni" (Powell és Myers 2017: 9; a szerzők fordítása).

\section{A gazdasági, társadalmi és fizikai környezet, illetve a sport mint lehetöség}

A fogyatékossággal élő emberek a szélesebb értelemben vett közösségeiket jellemző megannyi társadalmi-gazdasági folyamat szempontjából marginalizált helyzetben vannak, emellett gyakorta kerülnek ,körön kívül” a felzárkóztatást vagy fejlesztést célzó - így a sportalapú fejlesztéssel kapcsolatos - programok tekintetében is. Az integráció, illetve a beilleszkedés fő akadályai közé az előítéletesség és a diszkrimináció, a hozzáférhető közlekedési eszközök és sportinfrastruktúra, valamint a fogyatékossággal kapcsolatos igényeket és szükségleteket kielégítő megoldások, mint például a különféle segédeszközök hiánya tartozik (Devine, Carrol és munkatársai 2017).

Ahogy az egy az USA-ban és Ausztráliában lefolytatott kutatás eredményeiböl kitünik (Kean, Gray és munkatársai 2017), a gazdasági-, társadalmi- és fizikai környezet mind hatással lehetnek a sportolókra, illetve a sportolni vágyókra. A szóban forgó kutatásban az amerikai helyszín összes fontos létesítménye egy egyetemi campuson összpontosult, míg az ausztrál esetben néhány sportolónak nagy távolságot kellett megtennie annak érdekében, hogy választott sportágának hódolni tudjon. A kutatás mindkét esetben megállapította a pénzügyi támogatásnak/szponzorációnak - az adott sportág (ez esetben a kerekesszékes kosárlabda) szempontjából nélkülözhetetlen speciális berendezések költségeiben játszott - kiemelkedő szerepét. A szociális összetevők, mint például a minőségi, szakképzett edzők által nyújtott támogatás, szintén kulcsfontosságúnak bizonyultak. Összefoglalva, a két esettanulmány arra világít rá, hogy a (tömeg)közlekedési lehetőségek, a (speciális) felszerelések és eszközök, a hozzáférhető létesítmények és a mások által nyújtott segítség - nem meglepő módon számottevően befolyásolhatják a mozgáskorlátozottak sportolási lehetőségeit.

Annak ellenére, hogy a fentieknek megfelelően jóval több akadályt kell leküzdjenek, a fizikai vagy mentális/kognitív fogyatékossággal élő emberek egy része szervezett keretek közt vagy épp hobbijelleggel, de - rendszeresen sportol. A sport ezeknek az embereknek az életében megnyilvánuló egészségügyi előnyei - mint a 
kardiovaszkuláris betegségek, a diabétesz, a csontritkulás, illetve a rák kialakulásnak csökkent kockázata - közismertek. A kerekesszékes kosárlabda kapcsán például kimutatásra került, hogy sportolással eltöltött idö közel 65\%-ában a sportolók pulzusszáma a „magas” tartományban mozog (Seron, de Carvalho és Greguol 2019)

Az aktivitásnak az ülő életmóddal szembeni előnyei a fogyatékossággal élők esetén egész más módon is kidomborodnak, miként arra Di Russo és munkatársai egy 2010-es kutatásukban rámutattak. Az eredmények egyrészt azt támasztják alá, hogy az alsóvégtag-károsodott sportolók vizuális ingerekre adott, felső végtagokra vonatkozó motoros reakcióideje hosszabb, mint az ép nem-sportolóké. Ugyanakkor a tanulmány azt is kiemeli, hogy a nyílt mozgáskészségeket igénylő parasportok részlegesen kompenzálhatják a károsodást a motoros válaszok stabilitásának és rugalmasságának elősegítése révén. Magyarán a sport ilyen tekintetben is figyelemre méltó egészségügyi előnyökkel járhat (Di Russo, Bultrini és munkatársai 2010).

Lényeges ugyanakkor az is, hogy mely sport és milyen formán kerül kiválasztásra, hiszen kizárólag gondos előkészítést és megfelelő osztályozást követően biztosíthatók a fogyatékossággal élő sportolók számára a biztonságos sportolás körülményei. E sportolók bizonyos speciális adottságai, mint például a hőszabályozással kapcsolatos nehézségek vagy épp a latexallergia, illetve az állapotukhoz kapcsolódó egyéb szövődmények - érthető okokból - különös figyelmet érdemelnek.

A nehezítő körülmény dacára a fogyatékossággal élők sportolási lehetőségei és sporttal kapcsolatos aktív részvétele az elmúlt évtizedekben fokozatosan növekedtek, köszönhetően egyebek mellett annak, hogy egyre nagyobb figyelem irányul a fogyatékos sportolókra, a számukra elengedhetetlen feltételek biztosítására. A sportolók funkcionális adottságaik és teljesítő képességük alapján történő megfelelő besorolása, a fogyatékossággal kapcsolatos orvosi és ortopédiai feltételek biztosítása, valamint az adott fogyatékosság és a sport által támasztott követelmények figyelembe vételével megfogalmazott ajánlások mind komoly szerepet játszanak a megfelelő sportág kiválasztásában. Jóllehet, egy ép sportolónak jóval kevesebb ilyen tényezőt kell figyelembe venni, a legtöbb fogyatékossággal élő még így is számos sportág mellett dönthet anélkül, hogy a kockázatok miatt kellene aggódnia. Ez ugyanakkor egyáltalán nem jelenti azt, hogy az aktív életmódot ne kellene minden szinten ösztönözni és támogatni, illetve elősegíteni az abban való részvételt, akár a már említett pszichológiai és egészségügyi előnyök, akár a bevezetőben szóvá tett, a fogyatékossággal élök körében rendkívül alacsony részvételi hajlandóság okán. A megfelelő körülmények kialakítása magában kell, hogy foglalja többek között a sportolással kapcsolatos létesítmények biztosítását, az orvosi attitűd sportolást támogató irányba történő elmozdulását, a szakképzett segítők, edzők létszámának növelését, a fogyatékosággal élőkkel kapcsolatos ismeretek épek körében történő terjesztését, valamint a speciális igényü sportok és iskolai testnevelés pénzügyi támogatását (Patel és Greydanus 2010).

Figyelembe véve azt a körülményt, hogy Magyarországon a fogyatékossággal élők médiamegjelenése igencsak korlátozott, és maguk a fogyatékos emberek olyankor is jellemzően szociális kontextusban (tipikusan mint „probléma”) kerülnek bemutatásra (Right Communication Kft. 2014), az ismeretterjesztés/tájékoztatás kivételes hangsúllyal kell(ene) megjelenjen minden olyan szakpolitikában, mely a fogyatékos embereket érinti. Itt nem pusztán arról van szó, hogy jóval nagyobb figyelmet kellene, hogy 
kapjon a fogyatékos emberek társadalmi „hasznossága”, hanem az is fontos, kívánatos cél lenne, hogy artikulálódjanak a fogyatékos emberek számára rendelkezésre álló (vagy a jövőben elérhető) sportolási, szocializációs és egyéb közösségi lehetőségek, és az ezekben rejlő óriási potenciál, mely az egyes emberek életére hatás gyakorolhat.

Ilyen alapvető - és terjesztendő - információ, hogy a sport, vagyis a mozgás képes jelentősen mérsékelni az adott - értelemszerüen és elsősorban mozgásszervi jellegü - fogyatékossággal összefüggő inaktivitás egészségügyi kockázatait, illetve számottevően befolyásolni sportolók, illetve családjaik életét. Az elérhető speciális sportolási lehetőségek kapcsán széles körben hozzáférhetővé tett információk segíthetik az ülő életmódból eredően nagyobb kockázatának kitett embereket abban, hogy aktív életmódra törekedjenek, és ebbéli motivációjukat folyamatosan fenntartsák. A kellően és hatékonyan propagált információk egyúttal előmozdíthatják azt is, hogy a kerekesszékes vagy mozgásukban egyéb módon korlátozott emberek megfelelő létesítményeket, eszközöket, illetve szakembereket találjanak, akik/amelyek aztán nagyban hozzá tudnak járulni a sportolni vágyó emberek céljainak eléréséhez (Cooper és Tuakli-Wosornu 2018).

A funkcionális függetlenség, vagyis a fogyatékossággal élő embernek az a képessége, hogy a mindennapi élet alapvető tevékenységeinek ellátása érdekében a lehető legkevesebb külső segítséget vegye igénybe, egy további olyan komponens, amely meghatározó tud lenni az (elsődlegesen) mozgásukban korlátozott emberek esetén. Erre az adott segédeszközzel (kerekesszékkel) kapcsolatos készségek és mobilitás természetesen számottevő hatást gyakorolnak, vagyis az ilyen eszközt használó emberek számára elengedhetetlen e készségek-képességek elsajátítása a mindennapi élet legkülönbözőbb helyzeteiben felmerülő fizikai akadályok leküzdése érdekében. Márpedig igazolható pozitív kapcsolat áll fenn a kerekesszékkel kapcsolatos manuális készségek szintje, illetve a sport/sportolás mértéke között. A kerekesszékes sportolók a rendszeres edzés révén komoly gyakorlatra tehetnek szert az eszközhasználat terén, ebből eredően mobilitásuk, valamint funkcionális képességeik is jelentős mértékben javulhatnak nem-sportoló társaikkal összevetve (Saltan és Ankarali 2016).

A sportolásnak a fentieken túl további, figyelemre méltó hozadékai is vannak, melyek az egyének pszichés kondíciójával vannak összefüggésben. A mentális ellenálló képesség (Mental Toughness; MT) egy olyan, kulcsfontosságú pszichológiai változó, amely egy adott, (sport)teljesítménnyel kapcsolatos területen mutatott kitartással és az ott elért eredményekkel van összefüggésben. Az MT-t és annak fejleszthetőségét számos területen és sportág kapcsán vizsgálták már, azonban paralimpiai sportolók körében erre sokáig nem került sor. Az egyik első, erre fókuszáló tanulmány (Powell és Myers 2017) célja az volt, hogy a mentálisan erős paralimpikonok élettapasztalatain keresztül alkosson fogalmat az MT-ről és vizsgálja annak fejlődését/fejleszthetőségét. Az eredmények alapján arra lehet következtetni, hogy a paralimpikonok - amennyiben támogató közeg vette őket körül - nagyban képesek profitálni a rendkívül igénybevétellel járó helyzetekből, ami egyúttal a mentális ellenálló képességhez szükséges tulajdonságok és viselkedés, valamint az egyéni megküzdési módok és stratégiák kialakításához is hozzásegítette őket.

Egy másik kutatásban pedig arra sikerült bizonyítékot találni, hogy a kerekesszékes sportolók (ez esetben a kosárlabdázók) számos mentális funkció területén igencsak különböznek a nem-sportoló társaiktól. Ezek a sportemberek fejlet- 
tebb absztrakciós és problémamegoldó képességekkel rendelkeznek, a kompetitív dominancia igénye esetükben jóval alacsonyabb szintü, ugyanakkor magasabb fokú szorgalom, kitartás, megbízhatóság, felelősségérzet, magabiztosság, kiegyensúlyozottság, valamint a stresszhelyzetekkel szembeni ellenálló képesség jellemzi őket. Ezeken felül ráadásul még függetlenebbnek, józanabb ítélőképességünek, érzelmileg érettebbnek, és csoportban dolgozni képesnek mutatkoznak az inaktív életmódot folytatókkal összevetésben (Kasum, Lazarević és munkatársai 2011). Ezeket a megfigyeléseket támasztják alá Goodwin és kollégái kutatásai is (2009), akik kanadai kerekesszékes rögbijátékosokat vizsgáltak pszichés képességek szempontjából. A kutatásba bevont sportolók megnövekedett önbizalomról és kompetenciaérzésről számoltak be, amit a sportolói közösséghez való tartozásukhoz kapcsoltak, és aminek eredményeképpen - fogyatékosságuk ellenére - már nem érezték magukat izoláltnak. Sőt, a sport kapcsán megélt élményeik és az így szerzett tapasztalataik mind a pályán, mind az azon kívüli személyiségfejlődés szempontjából lényegesek voltak (Banack, Sabiston és Bloom 2011).

A sport fejlődése és elterjedtebbé válása- különösen a parasportok esetén - természetesen nem független a technológiai fejlődéstől. Az elmúlt évtizedekben a fogyatékossággal élő sportolók jelentősen növelni tudták teljesítmény szintjüket az eszközök modernizációjának és az egyénre szabott megfigyelések fejlödésének köszönhetően, vagyis az edzéstervek és rehabilitációs protokollok, illetve az orvosi ellátás és a táplálkozás monitorozásának hatékonyabbá válása révén (Schipman, Gallo és munkatársai 2019). Ugyanígy, a sportolásra használt kerekesszékek is komoly fejlödésen mentek keresztül ezen időszak alatt (Webborn 2011). A fogyatékos sportolók sikerének és fejlődésének megértése, a sportágspecifikus iránymutatások megfogalmazása pedig azt eredményezhetik, hogy az edzők a sportolás szintjének, jellegének és a sportolói korosztálynak megfelelően tudnak edzésterveket kialakítani. Ezek segítségével a sportolók számára egyértelmű ajánlások fogalmazhatók meg abból a célból, hogy valamennyien a számukra legkedvezőbb módon tudjanak bekapcsolódni az adott sportágba. Vagyis a fogyatékos sportolók fejlesztése, az adott sportágba való részvételük szempontjából igen lényeges a „testre szabott” edzésprogramok kialakítása (amely figyelembe veszi a különböző sportolók eltérő fejlesztési igényeit), illetve a sérülés jellegének és következményeinek mélyebb megértése annak érdekében, hogy a fogyatékossággal élő sportolók fejlődését bizonyítékalapú modellek révén is támogatni lehessen (Dehghansai, Lemez és munkatársai 2017). Az ilyenformán - vagyis akár az élsportok és élsportolók kapcsán - szerzett ismeretek alapul szolgálhatnak a fogyatékos/kerekesszékes emberek által mindennapi jelleggel használt segédeszközök optimalizálásához is (Perret 2017).

\section{Összegzés}

Jelen tanulmány elsődleges célja az volt, hogy áttekintést nyújtson az elmúlt 15 év fogyatékos sporttal kapcsolatos szakirodalma vonatkozásában, különös tekintettel a sportolói motivációkra, illetve a sportolni vágyó fogyatékos emberek általános és sporttal összefüggő körülményeire és lehetőségeire. A metaanalízis alapján több 
következtetést lehet levonni. Egyfelől a kutatók többsége egyetért abban, hogy a 2000-es évek eleje óta jelentős - alapvetően pozitív - változások történtek a fogyatékossággal élő emberek helyzetét illetően mind az Európai Unió (és természetesen Magyarország), mind az Egyesült Államok és Kanada területén. A biztató folyamat ugyanakkor közel sem jelenti azt, hogy minden szükséges lépésére sor került volna. Ez hazánk esetében is igaz, kiváltképp a sportolási lehetőségek, infrastruktúra és a tájékoztatás vagy épp a médiamegjelenések viszonylatában. Ennek megfelelően nagyon fontos lenne a társadalompolitika e területének még az eddigieknél is hangsúlyosabbá tétele, összhangban a jelen tanulmányban is bemutatott, a fogyatékossággal élőkre vonatkozó speciális igényekkel.

Fentiekből következően levonható az az általános érvényü tanulság, hogy igen előnyös lenne egy - sportolással kapcsolatos és azon túli - támogató környezet kialakítása, mely magába foglalja a nélkülözhetetlen eszközök és infrastruktúra, a megfelelö információk, a pszicho-szociális összetevők, így többek között a személyre szabott kognitív stratégiák, és minden olyan körülmény biztosítását, amely a társadalom e nagyszámú, ugyanakkor rendkívül heterogén csoportja szempontjából elengedhetetlen. Mindezek, illetve a fogyatékos emberek sportba való bevonása garantálhatják azt a fajta mentális jóllétet, amely a sok esetben nehezített körülmények dacára elérhető, és amelyre a most bemutatott kutatások is bizonyítékul szolgálnak.

\section{Irodalomjegyzék}

1. Banack H. R., Sabiston C. M., Bloom G. A. (2011): Coach Autonomy Support, Basic Need Satisfaction, and Intrinsic Motivation of Paralympic Athletes. Research Quarterly for Exercise and Sport (82), 4: 722-730. DOI: https://doi.org/10.5641/027013611x13275192111989

2. Bartosz M., Zubala T., Słyk K., Bigas G., Gryglewicz A., Kucharczyk B. (2010): Motivation of the disabled to participate in chosen Paralympics events (wheelchair basketball, wheelchair rugby, and boccia). Fizioterapia (18), 1: 4251. DOI: https://doi.org/10.2478/v10109-010-0044-5

3. Cooper R. A., Tuakli-Wosornu Y. A. (2018): Engineering and Technology in Wheelchair Sport. Physical Medicine and Rehabilitation Clinics of North America. (29), 2: 347-369. DOI: https://doi.org/10.1016/j.pmr.2018.01.013

4. Dehghansai N., Lemez S., Wattie N., Baker J. (2017): A Systematic Review of Influences on Development of Athletes With Disabilities. Adapted Physical Activity Quarterly (34), 1: 72-90. DOI: https://doi.org/10.1123/apaq.2016-0030

5. Devine A., Carrol A. és munkatársai Naivalu S., Seru S., Baker S., Bayak-Bush B., James K., Larcombe L., Brown T., Marella M. (2017): 'They don't see my disability anymore' - The outcomes of sport for development programmes in the lives of people in the Pacific. Journal of Sport for Development (5), 8: 4-18.

6. Di Russo F., Bultrini A., Brunelli S., Delussu A. S., Polidori L., Taddei F., Traballesi M., Spinelli D. (2010): Benefits of Sports Participation for Executive 
Function in Disabled Athletes. Journal of Neurotrauma (27), 12: 2309-2319. DOI: https://doi.org/10.1089/neu.2010.1501

7. Disabled World (2019): Disability Statistics: Information, Charts, Graphs and Tables

https://www.disabled-world.com/disability/statistics/; (Letöltve: 2019. 04. 05.)

8. Európai Bizottság (2010): Európai fogyatékosságügyi stratégia 2010-2020: megújított elkötelezettség az akadálymentes Európa megvalósítása iránt https://eur-lex.europa.eu/legalcontent/HU/TXT/PDF/?uri=CELEX:52010DC0636\&from=en; (Letöltve: 2019. 04. 05.)

9. Foucault M.(2000): Elmebetegség és pszichológia. A klinikai orvoslás születése. Budapest: Corvina

10. Kasum G., Lazarević L., Jakovljević S., Bačanac L. (2011): Personality of Male Wheelchair Basketball Players and Nonathlete Individuals with Disability. FACTA UNIVERSITATIS Series: Physical Education and Sport (9), 4: 407-415.

11. Kasum G. és Mladenović M. (2017): The Self-Perception of Athletes With Disability. PHYSICAL CULTURE (71), 1: 43-54. DOI: https://doi.org/10.5937/fizkul1701043k

12. Kean B., Gray M., Vendonck M., Burkett B., Oprescu F.(2017): The impact of the environment on elite wheelchair basketball athletes: a cross-case comparison. Qualitative Research in Sport, Exercise and Health (9), 4: 485-498. DOI: https://doi.org/10.1080/2159676x.2017.1311278

13. Központi Statisztikai Hivatal (2008): Nyári paralimpiák http://www.ksh.hu/szamlap/olimpia par.html; (Letöltve: 2019. 04. 05.)

14. Patel D. R., Greydanus D. E. (2010): Sport participation by physically and cognitively challenged young athletes. Pediatric Clinics of North America (57), 3: 795-817. DOI: https://doi.org/10.1016/j.pcl.2010.03.002

15. PerreaultS., Vallarand J. R. (2007): A Test of Self-Determination Theory with Wheelchair Basketball Players with and Without Disability. Adapted Physical Activity Quarterly (24), 4: 305-316. DOI: https://doi.org/10.1123/apaq.24.4.305

16. Pinczés Zsuzsi (2018): Mi változott a Taigetosz óta? - Hogyan tekint a társadalom a fogyatékossággal élőkre?

https://mindsetpszichologia.hu/2018/09/19/mi-valtozott-a-taigetosz-ota-hogyantekint-a-tarsadalom-a-fogyatekossaggal-elokre/; (Letöltve: 2019. 04. 05.)

17. Perret C. (2017): Elite-adapted wheelchair sports performance: a systematic review. Disability and Rehabilitation (39), 2: 164-172. DOI: https://doi.org/10.3109/09638288.2015.1095951

18. Powell A. J., Myers T. D. (2017): Developing Mental Toughness: Lessons from Paralympians. Frontiers in Psychology (8), 1270: 1-16. DOI: https://doi.org/10.3389/fpsyg.2017.01270

19. Right Communication Kft. (2014): Sporttal kapcsolatos kommunikáció a fogyatékossággal élők felé

http://sportmenedzsment.hu/wp-content/uploads/2014/06/Sporttal-kapcsolatoskommunik\%C3\%A1 ci\%C3\%B3-a-fogyat\%C3\%A9koss\%C3\%A1 ggal\%C3\%A91\%C5\%91k-fel\%C3\%A9.pdf; (Letöltve: 2019. 04. 05.) 
20. Saltan A., Bakar Y., Ankarali H. (2016): Wheeled mobility skills of wheelchair basketball players: a randomized controlled study. Disability and Rehabilitation: Assistive Technology (12), 4: 390-395. DOI: https://doi.org/10.1080/17483107.2016.1177857

21. Schipman J., Gallo P., Marc A., Antero J., Toussaint J. F., Sedeaud A., Marck A.(2019): Age-Related Changes in Para and Wheelchair Racing Athlete's Performances. Frontiers in Psychology (10), 256, 1-10. DOI: https://doi.org/10.3389/fphys.2019.00256

22. Seron B. B., de Carvalho O., Greguol M. (2019): Analysis of Physiological and Kinematic Demands of Wheelchair Basketball Games-A Review. Journal of Strength and Conditioning Research (33), 5: 1453-1462. DOI: https://doi.org/10.1519/jsc.0000000000003069

23. Szekeres Ágota (2011): Enyhén értelmi fogyatékos gyermekek szociális integrációja az általános iskola 4., 5. és 6. osztályában http://pszichologia.phd.elte.hu/vedesek/szekeres1.pdf; (Letöltve: 2019. 04. 05.)

24. Szepesi Anita (2018): Mellbevágó számok a fogyatékkal élő magyarokról https://www.napi.hu/magyar_gazdasag/mellbevago_szamok_a_fogyatekkal_elo magyarokrol.663531.html; (Letöltve: 2019. 04. 05.)

25. Webborn N. (2011): "What Do You Mean, A Wheelchair Athlete?" Current Sports Medicine Reports (10), 5: 246-247. DOI: https://doi.org/10.1249/jsr.0b013e31822d3d90

26. Wheelchair Foundation (2016): Wheelchair Needs in The World. https://www.wheelchairfoundation.org/programs/from-the-heart-schools-

program/materials-and-supplies/analysis-of-wheelchair-need/; (Letöltve: 2019. 04. 05.)

27. World Health Organization (2011): World Report On Disability https://www.who.int/disabilities/world_report/2011/report/en/; (Letöltve: 2019. 04. 05.) 